\title{
Benchlearning as Professional Development of School Leaders in
}

\section{Norway and Sweden}

\section{Authors of proposal including affiliations and email addresses}

Marit Aas, Associate Professor, University of Oslo, Norway, marit.aas@ils.uio.no ; corresponding author

Marit Aas is an Associate Professor at University of Oslo. Her research consists of School Management, School Development, Coaching. She has a background as a practitioner in school (teacher, principal, etc).

Thomas Blom, PhD student, Karlstad University, Sweden, thomas.e.blom@kau.se ; orcid.org/0000-0001-6789-537X ; phone +46-70-1914277

Thomas Blom is a PhD student in Pedagogical Work. Research interest is School Leadership and Trust. Thomas work at Karlstad University with The National School Leadership Program. He has a background as a practitioner in school (teacher, principal).

Acknowledgement:

Knut Roald, Western Norway University

Lillemor Rehnberg, Uppsala University 


\begin{abstract}
In this paper, we investigate a new national collaborative Benchlearning program for principals in Norway and Sweden. The Benchlearning program, which has been offered to 40-50 principals in the two countries, is a collaborative project between the Swedish and Norwegian National Agencies of Education. Four process leaders, two from Sweden and two from Norway, have been running the program. The aim is to give the participants the knowledge to develop a leadership practice and school environment that are more innovative. The program includes theoretical inputs, sharing experiences, school visits, training, and trialing of new leadership practices. Drawing on data from surveys, participants' reflections, and the leaders' descriptions of new leadership practice, we examine and identify successful and critical aspects of the learning process. The findings show that principals' motivation and willingness to start change processes can be created in a synergy between structured school visits, work in learning groups, and a theoretical foundation. Working in groups across schools in two countries seems to enhance principals' sense of efficacy, which in turn is shown to have a positive effect on their willingness to trial new practices. Two implications of the study are suggested. First, in the design of principal programs, systematic and critical reflection about authentic practice should be the basis. Second, educators should be trained to be process leaders who can support principals' learning during a critical and social construction of a new practice.
\end{abstract}

Keywords: school leadership, principal, professional learning, benchlearning, selfefficacy 
In its report on improving school leadership, the OECD (2008) concluded that we are preparing school leaders for a role that was designed for the industrial age, a role that has not changed enough to deal with the complex challenges of the twenty-first century. These complex challenges include managing change, building organizational capacity, implementing technological advances, increasing effectiveness, and striving to improve the learning outcomes of students (Fluckiger, Lovett, \& Dempster, 2014). Consequently, leaders may be required to assume the roles of education visionary, change agent, instructional leader, budget analyst, facility manager, and community organizer in their schools (Robinson, 2010). The need to develop a more innovative learning environment is also emphasized in the OECD report "Leadership for 21st Century Learning" (OECD, 2013b). There is a growing concern that the professional development of school leaders is lacking a robust research base and continues to be inadequate (Darling-Hammond, LaPointe, Meyerson, \& Orr, 2007; Philip Hallinger, 2011; Lovett, Dempster, \& Flückiger, 2015). In their analyses of eight highperforming school systems internationally, McKinsey and Company (2010) found that improvement of leadership capacity is an area where more has to be done.

According to Huber (2010), there is a need to create innovative approaches to improving school leaders' learning outcomes by providing opportunities for participants to acquire the knowledge and skills associated with evidence-based decision making. Each mode of learning — feedback, collegial exchange, courses, and self-studies—-must be drawn into a reciprocal relationship with practice to be effective. These arguments are supported in the study of Hammond et al. (2007), which recognizes the importance of problem-based learning situations that integrate theory and practice, that emphasize the management of school operations and leadership for school improvement, and that are accompanied by field-based projects, such as action research, analysis, and discussion of case studies, and a portfolio of 
evidence about practice. The paper sets out to show how leadership capacity can be developed through a Benchlearning program that includes a variety of learning opportunities.

In the first section, we lay the foundation for our research interest by examining international literature about strategies for school leadership development. We then briefly outline the content and learning strategies in the program. The next section describes the methodology, which includes a variety of data. Finally, we present the results and discuss the findings.

\section{Strategies for School Leadership Development}

In the literature, there is a consensus that school leaders need to comprehend the macro- and micro-contextual influences on their work, as well as to develop knowledge and skills to understand their schools. Furthermore, better student outcomes should be central to educational leadership, with principals leading the professional learning of teachers and participating in the learning themselves (Bush, 2009; Robinson, Hohepa, \& Lloyd, 2009; Stoll, 2007). However, despite universal agreement on this point, there is little research into how pedagogical leadership can be incorporated into leadership development programs and how to connect leadership and learning (Dempster, Lovett, \& Fluckiger, 2011). In an evaluation of school leadership programs in the USA, Darling-Hammond et al. (2007) identified eight programs that included many of the elements considered essential for pedagogical leadership; programs should, among other things, be based on research, incorporate organizational capacity building, change management and instructional knowledge, and change leadership skills.

An heuristic tool proposed by Clarke and Wildy (2011) and developed further by Lovett et al. (2015) offers clarity about the important learning topics in school leadership programs. The framework includes five focal points: understanding teaching and learning (referred to as pedagogy), understanding of the context (place), the people with whom 
leadership is enacted, the school as a part of a wider system satisfying its requirements, and the individual (the self) and his or her professional motivation, beliefs, values, and practices. Huber (2010) argues that when it comes to the learning processes, the transfer of knowledge to practice is crucial in leadership learning. He argues for a variety of strategies for professional learning, including cognitive and theoretical ways of learning (courses, lectures, and self-study), collegial (group work) and communicative process-oriented procedures (projects), and reflexive methods (feedback and self-assessment) (Huber, 2011) (see Figure 1).

\section{Insert Figure 1 here}

Figure 1. Approaches to learning in professional development (Huber 2011, p. 835).

Central to Huber's model is practical experience, illustrating how leaders' experience and practice are crucial in the learning process. This corresponds with Heck and Hallinger's (2014) argument that the purpose of leadership training is to give leaders the theoretical and practical knowledge that can lead to changes in their daily practice. The recognition of the link between practice and theory as a means of changing leaders' practice is also demonstrated in a study of school leaders participating in the Norwegian National Leadership Program (Aas, 2016). According to Hunzicker (2011), professional learning is considered relevant and authentic for adult learners when it is job embedded, instructionally focused, collaborative, supportive, and ongoing. This link with the real world of praxis is also emphasized by Kolb (1984), Cochran-Smith and Lytle (1999), and Robertson (2016). Hunzicker suggests that adults as learners are motivated by solving problems that relate directly to their lives and that create enduring solutions. Such connections to practice help the transfer of knowledge. 
Robertson (2013) declares that the learning of leadership is less about acquiring knowledge about leadership and more about thinking and making sense of current knowledge. This implies the necessity of learning and developing reflective skills (Dempster et al., 2011). According to Argyris and Schön (1978), reflection involves both single-loop and double-loop learning. Single-loop learning is defined as small adjustments to basic rules and procedures, while double-loop learning comprises new ways of thinking about and acting on issues. Hargrove (2008) argues that reflection also includes triple-loop learning, which involves consideration of the organizational context, as well as a dramatic shift in perspective and behavior. The necessity of including the development of metacognitive skills in leadership learning is also emphasized by Hallinger and Heck (2010).

In recent decades, studies on the benefits of coaching for professional development among school leaders have increased (Bush, 2009; Goff, Guthrie, Goldring, \& Bickman, 2014). Coaching provides a way to ensure that learning has direct relevance and meaning to a leader's work setting by helping leaders address practical issues and concerns and to make meaningful changes in their daily lives (Huff, Preston, \& Goldring, 2013; Mavrogordato \& Cannon, 2009). More recently, group coaching has become another variant of leadership coaching, the difference being the group effect that a learning community comprising school leaders representing a variety of school cultures and contexts can have on its members (Aas \& Vavik, 2015; Britton, 2010; Flückiger, Aas, Johnson, Lovett, \& Nicolaidou, 2016; Thornton, 2010). Group coaching is seen as providing support to leaders to put issues and concerns into perspective, to increase their efficiency and become innovative problem solvers, and to increase their attainment and capacity for learning (Gornall \& Burn, 2013; Grant \& Cavanagh, 2004; Tolhurst, 2010). Because group learning is also the focus in the program, we assume that the literature of group coaching is of relevance in this study, especially because group coaching appears to give participants the confidence to try out new learning opportunities in 
their institutions: They move from being reactive and isolated to being proactive (Aas \& Fluckiger, 2016; Robertson, 2013).

Self-efficacy is considered to be a cognitive component that is constructed through interactions between behavior and personal and contextual factors (Bandura, 1977). Because these beliefs are assumed to have a direct psychological effect on an individual's cognition, motivation, and affective state, self-efficacy is assumed to influence an individual's goals, choices, decisions, efforts, and quality of performance, as well as persistence in solving tasks (Bandura, 1997; McCormick, 2001). Previous research has revealed that leadership selfefficacy is positively associated with proactive behavior (Den Hartog \& Belschak, 2012), work engagement (Federici \& Skaalvik, 2011), job satisfaction, personal accomplishment (Federici \& Skaalvik, 2012), and trust in teachers and students (Tschannen-Moran \& Gareis, 2004). A study of school leadership preparation programs suggests that building relationships, collaborative work, authentic learning opportunities, and learning from others were important factors for developing principal self-efficacy (Versland, 2009). The importance of authentic learning is supported by Webster-Wright (2009, p. 727), who argues that although "no one can make another person learn, professionals can be supported to continue to learn in their own authentic way while taking into account the expectations of their working contexts." On the basis of the literature on the professional learning of school leaders, Huber (2010) recommends that the participants' authentic practice has to be the main concern in their learning. In the next section, we will describe the context of the Benchlearning program and how the content and learning methods are inspired by the reflective action-oriented view of learning.

\section{The Benchlearning Program}


The educational policies of Sweden and Norway reflect many similarities regarding educational ideologies, such as a comprehensive education system, a strong state, loyalty to and acceptance of state governing, and municipalities as relatively independent political institutions (Møller, 2009; Nihlfors \& Johansson, 2013). Compared to other countries, Norway and Sweden have a large public sector, and local municipalities play a strong role in school governance. ${ }^{1}$ The municipality finances the schools, employs the principals and the teachers, and plays a key role in providing in-service training for teachers and principals. The two countries' education systems are predominantly public, which means that state authorities run most schools and universities. Education is free at all levels. There is no streaming according to ability, gender, or other factors, and most students are enrolled in regular classes. Since the end of the 1980s, the education systems in both countries have undergone major reforms, influenced largely by new managerial ideas. Despite the many similarities between Norway and Sweden, there are also some differences. They have developed different national assessment systems (Skott, 2013), and while Sweden during the last 15 years has broadly opened up for independent schools, Norway has a rather limited private sector (Møller \& Skedsmo, 2013).

The Benchlearning program is a bilateral collaborative learning program for principals in Norway and Sweden. The program, which has been offered to $40-50$ principals in the two countries, is a collaborative project between the Swedish and the Norwegian National Agencies of Education. Four process leaders, two from Sweden and two from Norway, have been running the program. The process leaders are all running national principal programs in the two countries. The aim of the program is to give the participants the knowledge to develop a leadership practice and school environment that are more innovative, inspired by the two OECD reports “Innovative Learning Environments" (OECD, 2013a) and "Leadership for 21st

\footnotetext{
${ }^{1}$ The 429 municipalities in Norway and 290 in Sweden are responsible for compulsory education at the primary and lower-secondary school levels. The municipalities vary in size as well as in levels of welfare.
} 
Century Learning" (OECD, 2013b). The design of the program includes theoretical inputs, sharing experiences, school visits, and training in new leadership practices, as shown in Figure 2.

Insert Figure 2 here

Figure 2. The design of the program.

The program consists of two meetings, one in Sweden (module one) and one in Norway (module two). Each meeting is two and a half days long, with about six months in between. The participants are divided into learning groups consisting of principals from both countries and within the same type of school. These groups work together throughout the whole program. Before module one, the participants prepare themselves by reading texts about innovative learning environments and learning leadership. They also reflect on the learning environment at their own school, on what it means for the school and for themselves as principals, as a preparation for conversations in the learning group at the first meeting.

Module one starts with a short theoretical input as a context marker. Focus is set early on the topics, and by training to see without judgment and be aware of how previous experiences have influenced them, the participants prepare for the school visit. The theoretical frame, innovative learning environments and learning leadership, creates a screen to help participants describe what they see during the school visits and to analyze and reflect with regard to theory. The first module ends with the participants identifying aspects that they will be curious about and will look for in their own school, what they would like to try out or develop at their schools, and what their next step will be. In between the meetings, the participants write down their reflections on what they do at their schools. Then, after six 
months, they write down what they have proceeded with and what experiences they obtained from doing so. On each occasion, they put their reflections on a collaborative learning platform, Google Drive, which is used during the program. The platform is transparent in order to increase participation, and to enhance sharing and learning from each other's reflections and experiences.

The second module is in Norway and starts with the participants exchanging information about their experiences of what they have done at their schools in the period between module one and two, as well as their reflections on the process and the literature. Using theory and experience, they once again prepare for a second school visit, with the subsequent description, analysis, and reflection, as in module one. This module also includes a theoretical input, this time based on the participants' own reflections and questions about innovative learning environments, learning leadership, and school development. The program ends with the learning groups reflecting upon the process and what they learned, and an individual reflection that includes a short description of what they will continue to develop at their schools and in their own leadership.

\section{Methods}

In this article, we draw on data from the two groups who completed the program, in June 2015 and June 2016, respectively. The data are based on individual reflection documents from students on their learning and new leadership practices six months after the end of the program. In addition, the Norwegian Directorate of Education conducted an online survey of participants about their experiences of the program, and there are a number of documents produced in the learning groups on Google Drive throughout the program. The last includes individual reflection documents made before the program began, in the intervening period, and at the end, all related to the participants' own learning, the learning groups' preparation for school visits, their analysis, and the final school reports. Together, the documents on 
Google Drive provide a longitudinal perspective on the participants' learning. When it comes to the survey and process documents on Google Drive, the data are not subject to systematic analysis in this article. However, they form a contextual backdrop for the analyses. In sum, the survey and process documents provide a picture of great satisfaction on the part of the participants but also a glimpse of how challenging it is for school leaders to understand and manage the complexities they face in their daily practice.

After the last meeting, the participants were encouraged to draw up reflection documents on the practice changes they had worked with as a result of participation in program - and reflections on their efforts to introduce these changes. A letter from the Norwegian and Swedish Directorate of Education explained that the reflections could be organized according to the following questions:

1. What changes have been implemented, and why?

2. How has the program helped to support you in the implementation of changes?

3. What obstacles have you experienced in the effort to change practices?

4. How have you overcome the obstacles?

5. How does this develop on previous practices?

6. Other comments or reflections

Twenty-five of the Norwegian participants and 11 of the Swedish participants in the program sent in reflection notes with rich descriptions of 4-10 pages. The participants in the program comprised about 60 percent women and 40 percent men. Their length of service as a principal varied from a couple of years up to about ten years. The participants from Norway have conducted the national school leadership development program and attended the 
Benchlearning program as skills development, whereas the Swedish participants were offered the Benchlearning program during their last year in the national school leadership development program. The principals represented different school levels, such as elementary schools and upper secondary schools, and their schools were situated in all regions of the two countries. Since the reflection notes should be anonymous and the number of participants was small, we did not ask them to write down personal information in the reflection papers. We have chosen to focus on principals, and therefore we have not taken gender into account. In the presentation of these empirical findings, we refer to the different reflection documents through coding: P1, P2, etc. Methodologically, we have chosen a discursive approach to the analysis of documents. Discursive analysis aims to clarify how certain patterns in texts emerge from certain main ideas that underlie the texts (Fairclough, 2003; Grønmo, 2004). In the first reading, each of the documents was analyzed in order to understand the whole (vertical). For the second reading, the documents were analyzed by comparing all answers to question 1 , to question 2, etc. (horizontal). We used content analysis to identify successful and critical aspects of the learning process of the participants, especially the leaders' motivation, engagement, and willingness to transform their daily practice. We discussed the strength and weaknesses of the learning approach and how this type of leadership program could support leaders' learning. The data was analyzed country by country, but due to very similar responses, we chose to present our findings according to our questions, without distinguishing between the two countries.

\section{Results}

Across the different data resources (survey, documents on Google Drive, and reflections from the students), there is agreement about the positive effects of the program, both at the end of the program and six months later. However, in the presentation of the findings, we focus on possible links between the program and new practices in the schools. 
We report on the four main issues in the students' reflection papers: (1) Changes in leadership and school practice, (2) the program's contribution to the school's development, (3) challenges in the school's development, and (4) other comments and reflections. Excerpts from the participants' voices (referring to P1, P2,...) are used to exemplify and illustrate our findings, representing participants from both countries.

\section{Changes in Leadership and School Practice}

Several of the participants describe how they have established both organizational and digital structures and starting-up processes to enable collective learning to strengthen teaching in order to raise school achievement. Many of the descriptions concern starting conversations about the relationship between students' grades and teaching quality. One participant says,

"We have moved from a strong focus on the assessments of student achievement in developing formative assessment, collective learning, and an intercultural approach" (P3). One method is to make structures for disciplined and focused conversations, as well as follow-up meetings and conferences with participants in the school. This includes solutions that are more flexible, which, for example, give students the opportunity for project time, as one participant explains: "We have more flexible solutions, expanded teacher collaboration, and projects for the students to be able to affect the quality of teaching" (P6). How digital systems can be used among others to make educational plans public is emphasized. One example of use of digital systems is reported by one of the principals: "We have more active staff conferences, with digital support both during and after the conference time: sharing of documents, apps for quick follow-up" (P10).

Several participants also report that they have worked to revise and construct clarity in their leadership role, as well as in the responsibilities, distributions, procedures, and structures of the organization, based on the school's educational platform. One participant reports that he has been more structured in his work on the school's pedagogical commitment: "I have 
established routines and structure in accordance with the school's educational platform" (P2). This also includes highlighting various leadership positions and strengthening and clarifying the student health team's approach and skills, as well as team leaders' roles and mandates. It has initiated an organization that provides opportunities for flexible working groups that can respond to identified needs. These changes can be summed up by a comment from one of the principals: "We now have flexible working groups based on identified needs" (P2).

A third category of answers concerns the different activities and development processes to take advantage of and coordinate initiatives and development work, often associated with forms of distributed leadership. One principal describes the experiences of a more distributed leadership practice as follows:

I practiced distributed leadership in change processes for Information Technology, alternative groupings, and a multidisciplinary approach. Three of the teachers ran workshops and gave colleagues tasks instead of me. About half of the teachers ran various development projects. (P10)

\section{The Program's Contribution to School Development}

The most frequent answer on how participation in the program had contributed to development work concerned how the visits to the schools were prepared and processed. The importance of how theory enhanced their understanding of the school visit is expressed in the following comment from one principal: "I emphasized the strong and direct link between theoretical discussions and a very well-prepared visit in practice" (P1). It also describes the significance of seeing something familiar in the visited school. To see how something can be manifested in practice creates conditions for daring to do it yourself, as expressed in the 
following comment: "When you get concrete practical ideas to talk about and a picture of how change is possible, it helps you to believe that you can do the same" (P5).

Literature and discussions, combined with the group's role, are also highlighted as a good contribution. These concern how the different small groups were composed and given tasks, as well as the good climate that created the framework for good conversation $(\mathrm{P} 2, \mathrm{P} 3$, $\mathrm{P} 5, \mathrm{P7})$. A group with something in common while, at the same time offering differences, is described by one principal as both supportive and challenging (P2, P10).

In conversations with colleagues from other schools and within an inclusive climate, it is possible to get oneself and one's school mirrored. We were different enough that I had to think beyond that which would otherwise have been perceived as fixed structures and unyielding conditions. (P2)

Most of the participants highlighted how the obligatory work tasks between the seminars helped them to start and continue development work in their own school. The fact that they had to document the process on Google Drive and for their learning group was a pressure that assisted them in their daily leadership. How the program forced them to find time for reflections is exemplified by one of the principals: "When every day is as hectic as it is, it's good to be 'forced' to spend time for reflection and reasoning” (N19).

The learning group with participants from both countries seemed to enhance the development of the participants' leadership role and practice in many ways. Sharing experiences across organizational cultures within different countries and municipalities enriched the participants' understanding of context-based leadership. The school visits supported this knowledge. The following comment from one of the participants underlines the two-country effect: "The biggest impact of the Benchlearning Program came from the well- 
prepared school visits and the work in the learning group that included principals from both Norway and Sweden" (N3).

Some of the students argued that the design and content of the program had provided models to relate to and then model in their own school. Examples of methods the participants described as useful are expressed in comments from three of the participants:

"The possibility that Google Drive gave in terms of transparency and accessibility to documentation and experiences was important." (P1)

"The program gave many models that could be transferred directly to my own school and practiced together with my teachers." (S4)

"I have picked up models from the school visit and practical tools and methods from the discussions in the big group." (P5)

\section{Challenges in School Development}

When it comes to challenges in the change process, the students report on everyday issues, such as redundancies, discussions of time and structure, changes in political governance, and an economy that requires quick adjustments. Parents' concerns about a new approach when it comes to flexible solutions often involve a challenge that must be met. Several students argue that different school size also affects the conditions for the work of development. Another challenge mentioned was the situation in which a school has many new teachers and it becomes necessary to take time and not rush. A large school where there are many different professional cultures and diverse educational backgrounds is also challenging. It is easy to lose focus in the long and often slow process in which many different actors are 
involved. All these descriptions recognize that it is difficult to get everyone pulling in the same direction, as one of the participants explained: "It must be an extraordinary collaboration, with much dialogue and cooperation and a well-thought-out strategy of shortand long-term goals, and where the value of all the roles in the school system are made visible" (P6).

Some of the responding students explained how they handled the challenges described. This could involve preparatory and ongoing meetings with different actors in the school, including union representatives, in order to reformulate the goals and objectives so that they fit into a new model. Some chose to introduce changes in line with the processes going on at the school, which required a series of meetings and discussions with new staff.

\section{Other Comments and Reflections}

Several participants described how participating in the program had influenced their thinking about change. Others recounted how the documents distributed during the program had been used in their school, which was perceived as having improved the efficiency of their process and made it possible to show educators how other schools work (P4). The same participants also believed that it was just as powerful when school leaders learned from each other as when teachers did it, and they also hoped to offer the teachers at the school the opportunity to see, hear, and talk with other colleagues from other schools, as one principal said: "The program has also meant that it has created networks and Facebook groups where school leadership issues and concerns are raised" (P1). Another participant recalled recently completed development work in which there had been a strong bottom-up perspective and the perception of a common collective learning had been the basis. Choosing and following a selected focus area was also given as an example of a changed way of working with development processes. 
Some described a new approach to leading change processes. They recounted how they had involved more teachers "in practice," and consequently there had been a strong bottom-up perspective. Others say that the leaders had been more active and that the leadership team had had more discussions about a common approach to the development work. The combination of the both light-hearted and serious was said to have been very pleasing, as one participant noted: "We quickly got to know each other and knew just the right bit of our countries' school systems to ask nosy questions" (P5).

\section{Changes of Practice}

As mentioned earlier, the data from the process documents the participants produced during the program were not subject to systematic analysis in this article, but form a contextual backdrop for the analyses. In sum, the process documents, together with the presented findings, provide a picture of changes in practice. Different themes from the process documents can also be seen in the participants' reflections after six months.

Table 1. Changes in Practice

Insert Table 1 here

In the following discussion, we look at the results in light of the literature on professional knowledge and how professionals learn from a range of activities, through interaction with colleagues, and in differing combinations (Webster-Wright, 2009) as illustrated in Huber's (2011) model of learning (see Figure 1).

\section{Discussion}

On the basis of the empirical data, we will focus mainly on the left side of Figure 1, because this side of the model shows the learning interactions that seem to be most powerful, 
namely, the interaction of personal feedback, professional learning groups, and practice, as shown in Figure 3.

Insert Figure 3 here

Figure 3. The interaction between feedback, professional learning groups, and practice.

\section{Practice is the Core Issue in Learning}

The analysis of data shows how the observations that participants made during school visits, talks they had in learning groups, and the theory they have been presented in the form of literature, short lectures, and group work, inspired them to start or continue the development of their own school. According to the participants, it is precisely the variety of learning strategies, with the common focus on practice that has provided the synergy of the courage to learn and the desire to learn. Practice, which is the core element of Huber's model, in this study was understood in four ways: (1) students' own practices and (2) the colleagues' practices, both expressed through sharing experiences in the learning group; (3) practice in real life, observed as a mirroring process in the school visits; and (4) research-based knowledge about practice, given in lectures.

Practice is the essential part of all the conversations, because it is what the participants have in common as principals. Practice is also the link between theory and practice (CochranSmith \& Lytle, 1999; Kolb, 1984), and as the analysis shows, the students use the theory to enhance their own understanding and to find a repertoire of solutions in change processes, for example, by using the seven criteria for innovative learning or distributed leadership (OECD, 2013a, 2013b). Theoretical knowledge and a broader practical understanding of how leadership can be performed in change processes seem to increase the students' motivation 
(Hunzicker, 2011) and self-efficacy (Bandura, 1977), and to foster a more proactive behavior (Den Hartog \& Belschak, 2012).

\section{Learning Groups}

Compared to what we know from studies of group coaching (Aas \& Fluckiger, 2016), the students seem to acknowledge how the learning environment in the group helps them to see issues and concerns from alternative perspectives, and then to increase their attainment of and capacity for learning (Gornall \& Burn, 2013; Grant \& Cavanagh, 2004). Many of the participants commented on the climate that quickly established itself in the learning groups and how they quickly became familiar with each other during the collective tasks on which they worked. The visibility, transparency, and accessibility of the ongoing work within the whole learning group also inspired similar work in the students' own schools. Several report that the development had, to a greater extent than previously, a bottom-up perspective and that the leaders had been more involved in the conversation and ongoing processes, both before and during the actual development. The arrangement of the groups, with Norwegian and Swedish principals from similar schools, meant that they had enough in common to understand and recognize each other, while there were enough differences to create and sustain curiosity. Nothing could be fully taken for granted when the mixture of the recognizable and the unfamiliar that was investigated in groups called on the common experience that the study visits gave.

\section{Personal Feedback}

In addition, the feedback they received and gave to each other, both in seminars and in the form of document sharing to Google Drive, seems to have promoted reflection and looped learning (Argyris \& Schön, 1978), including adjustments to basic rules and procedures (single-loop learning), new ways of thinking and acting (double-loop learning), and dramatic shifts in perspective and behavior (triple-loop learning). As demonstrated in Table 1, the 
students seem to relate new ideas to their own context, and they supported each other in making changes in both their leadership practice and the school structure. Both the personal feedback process in the group and the follow-up routines in the program design seem to enhance personal commitment. When several students report on the development of the learning environment for both students and teaching staff, which includes changing structures of organization, roles, and mandates, we can talk about triple-loop learning (Hargrove, 2008).

\section{The Role of the Process Leaders}

In order to promote conversations and processes, during the two seminars, and in the period between, the process leaders had to balance between being demanding and supportive. The demanding role included asking the students to write personal reflections, preparing and analyzing the school visits, reading and using theory in discussions and analysis, trialing new leadership practices, and reporting on the changes. The supportive role was to follow up the different student tasks. As Figure 3 shows, the critical role of the process leaders was to enhance reflections on individual and collective levels. Development of the participants' reflexive skills is emphasized as one of the success criteria in school leaders' professional development (Dempster et al., 2011). The idea of having an overall theoretical focus (innovative learning) that followed the students in their investigations of their own practice during the school visits and the conversations in the group helped to increase reflection to a higher level that could lead to more learning (Robertson \& Earl, 2014). According to Hallinger and Heck (2010), theory can help participants to obtain an extended context of understanding by comparing their own leadership practices with generalized knowledge.

\section{Practice Changes}

According to Robertson (2013), it is not often that leadership learning leads to changes in school leaders' practice after completing their training program. The summary of the participants' practice changes six months after the end of the program (Table 1) shows that 
the program inspired the participants and led to new practices in four areas: a) development of distributed leadership, b) greater emphasis on collegial professional development related to the workplace, c) the seven Innovative Learning Environment (ILE) principles as the foundation for the school's development, and d) management of the school's digital development. Common to these areas was that they were illuminated through literature studies, lectures, experience exchanges, and visits to schools, and that participants tried out some of the ideas in their own school. According to participants' feedback, they received the motivation to change their leadership approach, such as more distributed practices. The work process is an example of how knowledge can be transformed into practice (Cochran-Smith \& Lytle, 1999).

\section{Triangular Synergy between Investigating Authentic Practice, Work in Learning Groups, and Personal Feedback}

A number of key themes have been identified as important in the study of the participants' learning and trialing of new leadership practice. Although all of these elements have been effective, it is the interaction between them that has generated the positive effect. We suggest that there is triangular synergy between investigating authentic practice, work in learning groups, and personal feedback. First, in the program, the participants investigated authentic practice by sharing experiences in learning groups and school visits. The investigations were characterized by questions and reflections, and the learning was reinforced by the process leaders' inductive work, through challenging and productive questions and by using Google Drive, both in the meetings and the intermediate work. These findings are in line with Heck and Hallinger (2014), who suggest stimulating school leaders to ask questions about their own leadership practice in order to help them to make meaningful changes in their everyday practice. Second, providing learning opportunities based on building relationships between the participants in their learning groups has made a shift from 
knowing and learning, away from the minds of the individual participants toward a socially contracted practice. Third, personal feedback, through collaborative work based on authentic practices and learning from others, seems to increase principal self-efficacy (Den Hartog \& Belschak, 2012; Versland, 2009) and motivation to trial new leadership practices.

We will argue that the results of this study capture what Webster-Wright (2009) calls "authentic professional learning," defined as learning that is embodied, contextual, situated, social, and constructed. However, when learning occurs through practical experience and reflective action within contexts, dilemmas will appear, and the difficulties and limitations arising from such experiences and research will evolve (Webster-Wright, 2009).

\section{Limitations}

All participants were invited to a third meeting, which focused on learning from practice. We asked the participants to write down their reflections regarding a few open questions and to discuss our tentative findings. The data used in this paper, to follow the participants' school and leadership development, came from these reflections. One limitation is that we only have data from these participants, not from those who did not participate. This could be a bias. The paper answers the questions regarding that particular selection of principals, who aimed to participate in the third meeting. Due to the focus in this paper, we limited our presentation of findings regarding gender. Similarities and differences between the two countries were small but can be analyzed in greater depth if questions arise about whether the participants' different backgrounds have an impact.

\section{Conclusion and Implications}

This article sets out to show how leadership capacity can be developed through a Benchlearning program that includes a variety of learning opportunities. Overall, this article demonstrates that the program contributed to increased commitment, motivation, and confidence to make changes in the participants' own schools and, after finishing the program, 
including changing their leadership practices. The findings must be seen in light of the fact that the participants had taken part in the national principal program and that they had applied for participation. Therefore, we expected that the participants' knowledge of and motivation for school development already was substantial. As the analysis shows, many participants had already started innovative work at their own schools, but the program helped to reinforce and sharpen this work.

The implications of the study can be summed up in following four principles: First, policymakers should take into account the fact that principals' motivation and willingness to initiate change processes can be created in a synergy between structured school visits, work in learning groups, and a theoretical foundation. Second, the individual principal increases his/her self-efficacy within the socially contracted practice in the learning group. Third, a systematic reflection process about authentic practice is an example of how principals can develop their metacognitive capacity and how knowledge can be transformed into new practice. Fourth, educators should be trained to be process leaders who can balance between being demanding and supportive in principals' learning and their new leadership practice. 


\section{References}

Aas, M. (2016). Leaders as learners: developing new leadership practices. Professional Development. doi:10.1080/19415257.2016.1194878

Aas, M., \& Fluckiger, B. (2016). The role of a group coach in the professional learning of school leaders. Coaching: An International Journal of Theory, Research and Practice, 9(1), 38-52. doi:10.1080/17521882.2016.1143022

Aas, M., \& Vavik, M. (2015). Group coaching: a new way of constructing leadership identity? School Leadership \& Management: Formerly School Organisation, 35(3), 251-265. doi:10.1080/13632434.2014.962497

Argyris, C., \& Schön, D. A. (1978). Organizational learning a theory of action perspective. Reading, Mass.: Addison-Wesley.

Bandura, A. (1977). Self-efficacy: Toward a unifying theory of behavioral change. Psychological Review, 84(2), 191-215.

Bandura, A. (1997). Self-efficacy: the exercise of control. New York: Freeman.

Britton, J. J. (2010). Effective Group Coaching. Tried and Tested Tools and Resources for Optimum Coaching Results. Hoboken, NJ, USA: John Wiley\&Son.

Bush, T. (2009). Leadership development and school improvement: contemporary issues in leadership development. Educational Review, 61(4), 375-389. doi:10.1080/00131910903403956

Clarke, S., \& Wildy, H. (2011). Providing professional sustenance for leaders of learning: the glass half full? In T. Townsend \& J. MacBeath (Eds.), International handbook of leadership for learning. (pp. 673-690). Dordrecht: Springer.

Cochran-Smith, M., \& Lytle, S. L. (1999). Relationship of Knowledge and Practice: Teacher Learning in Communities. In A. Iran-Nejad \& C. D. Pearson (Eds.), Review of Research in Education (Vol. 24, pp. 249-306). Washington DC: American Research Association.

Darling-Hammond, L., LaPointe, M., Meyerson, D., \& Orr, M. (2007). Preparing school leaders for a changing world: Lessons from Exemplary Leadership Development Program. Retrieved from Stanford, CA: http://seli.stanford.edu

Dempster, N., Lovett, S., \& Fluckiger, B. (2011). Literature review: Strategies to develop school leadership. The Australian Institute for Teaching and School Leadership.

Den Hartog, D. N., \& Belschak, F. D. (2012). When does transformational leadership enhance employee proactive behavior? The role of autonomy and role breadth self-efficacy. Journal of Applied Psychology, 97(1), 194-202. doi:10.1037/a0024903

Fairclough, N. (2003). Analysing discourse. Textual analysis for social research. London and New York: Routledge.

Federici, R., \& Skaalvik, E. (2011). Principal self-efficacy and work engagement: Assessing a norwegian principal self-efficacy scale. Social Psychology of Education, 14(4), 575600. doi:10.1007/s11218-011-9160-4

Federici, R., \& Skaalvik, E. (2012). Principal self-efficacy: Relations with burnout, job satisfaction and motivation to quit. Social Psychology of Education, 15(3), 295-320. doi:10.1007/s11218-012-9183-5

Fluckiger, B., Lovett, S., \& Dempster, N. (2014). Judging the quality of school leadership learning programmes: an international search. Professional Development in Education. doi:10.1080/19415257.2014.902861

Flückiger, B., Aas, M., Johnson, G., Lovett, S., \& Nicolaidou, M. (2016). The potential of group coaching for leadership learning. Professional Development in Education. doi:http://dx.doi.org/10.1080/19415257.2016.1223736 
Goff, P., Guthrie, E., Goldring, E., \& Bickman, L. (2014). Changing principals' leadership through feedback and coaching. Journal of Educational Administration, 52(5), 682704. doi:http://dx.doi.org/10.1108/JEA-10-2013-0113

Gornall, S., \& Burn, M. (2013). Coaching and learning in schools: A practical guide. London: SAGE.

Grant, A. M., \& Cavanagh, M. J. (2004). Toward a profession of coaching. Sixty-five years of progress and challenges for the future. International Journal of Evidence Based Coaching and Mentoring, 2(1), 1-16.

Grønmo, S. (2004). Samfunnsvitenskapelig metode. Bergen: Fagbokforlaget.

Hallinger, P. (2011). Leadership for learning: lessons from 40 years of empirical research. Journal of Educational Administration, 49(2), 125-142.

Hallinger, P., \& Heck, R. H. (2010). Leadership for Learning: Does Collaborative Leadership Make a Difference in School Improvement? Educational Management Administration \& Leadership, 38(6), 654-678. doi:10.1177/1741143210379060

Hargrove, R. A. (2008). Masterful coaching (3rd ed.). San Francisco: Jossey-Bass Pfeiffer.

Heck, R. H., \& Hallinger, P. (2014). Modeling the longitudinal effects of school leadership on teaching and learning. Journal of Educational Administration, 52(5), 653-681. doi:http://dx.doi.org/10.1108/JEA-08-2013-0097

Huber, S. G. (2010). New approaches in preparing school leaders. In P. Peterson, E. Baker, \& B. McGaw (Eds.), International encyclopedia of education (Vol. 4, pp. 752-761): Oxford: Elsevier.

Huber, S. G. (2011). Leadership for learning - Learning for leadership: The impact of professional development In T. Townsend \& J. MacBeath (Eds.), Springer International handbook of leadership for learning. Springer International Handbooks of Education 25. (pp. 635-652). Dordrecht: Springer.

Huff, J., Preston, C., \& Goldring, E. (2013). Implimentation of a coaching program for school principals: Evaluating coaches' strategies and results. Management, Administration and Leadership, 41, 504-526. doi:10.1177/1741143213485467

Hunzicker, J. (2011). Effective professional development for teachers: a checklist. Professional Development in Education, 37(2), 177-179.

Kolb, D. A. (1984). Experiential learning experience as the source of learning and development. Englewood Cliffs, N.J.: Prentice-Hall.

Lovett, S., Dempster, N., \& Flückiger, B. (2015). Personal agency in ledership learning using an Australian heuristic. Professional Development in Education, 42(1), 127-143. doi:10.1080/19415257.2014.891532

Mavrogordato, C., \& Cannon, M. (2009). Coaching principals: a model for leadership development. Paper presented at the annual meeting of the University Council of Educational Administration, Anaheim, CA.

McCormick, M. J. (2001). Self-efficacy and leadership effectiveness: Applying social cognitive theory to leadership. Journal of Leadership \& Organizational Studies, 8(1), 22-33. doi:10.1177/107179190100800102

McKinsey \& Company. (2010). Capturing the leadership premium: how the world's top school systems are building leadership capacity for the future (Publication no. http://mckinseyonsociety.com/downloads/reports/Education/schoolleadership_final.pd f). Retrieved 09.02.2015

OECD. (2008). Improving School Leadership: Policy and Practice. Paris: Organisation for Economic Cooperation and Development.

OECD. (2013a). Innovative Learning Environments. Paris: OECD Publishing.

OECD. (2013b). Leadership for 21st Century Learning, Educational Research and Innovation. Paris: OECD Publishing. 
Robertson, J. (2013). Learning leadership. Leading and Managing, 19(2), 54-69.

Robertson, J. (2016). Coaching Leadership: Building Educational Leadership Capacity through Coaching Partnerships (Second ed.). Wellington: NZCER PRESS.

Robertson, J., \& Earl, L. M. (2014). Leadership learning: Aspiring principals developing the dispositions that count. Journal of of Educational Leadership, Policy and Practice, 29(2), 3-17.

Robinson, V. M. J. (2010). From Instructional Leadership to Leadership Capabilities: Empirical Findings and Methodological Challenges. Leadership and Policy in Schools, 9(1), 1-26.

Robinson, V. M. J., Hohepa, M., \& Lloyd, C. (2009). School leadership and student outcomes: Identifying what works and why. Best evidence synthesis iteration Wellington: Ministry of Education.

Stoll, L. (2007). Professional learning communities: elaborating new approaches. In L. Stoll \& K. S. Louis (Eds.), Professional learning communities: divergence, depth and dilemmas (pp. 1-14). Maidenhead: McGraw-Hill/Open University Press.

Thornton, C. (2010). Group and Team Coaching. The Essential Guide New York: Routledge.

Tolhurst, J. (2010). The essential guide to coaching and mentoring (2nd ed.). Harlow, UK: Pearson Education.

Tschannen-Moran, M., \& Gareis, C. R. (2004). Principals' sense of efficacy: Assessing a promising construct. Journal of Educational Administration, 42(5), 573-585. doi:10.1108/09578230410554070

Versland, T. (2009). Self-efficacy development of aspiring principals in education leadership preparation programs. (Unpublished doctoral dissertation), Montana State University, Bozeman, MT. (UMI Number 3350325). 


\section{Figures and Tables}

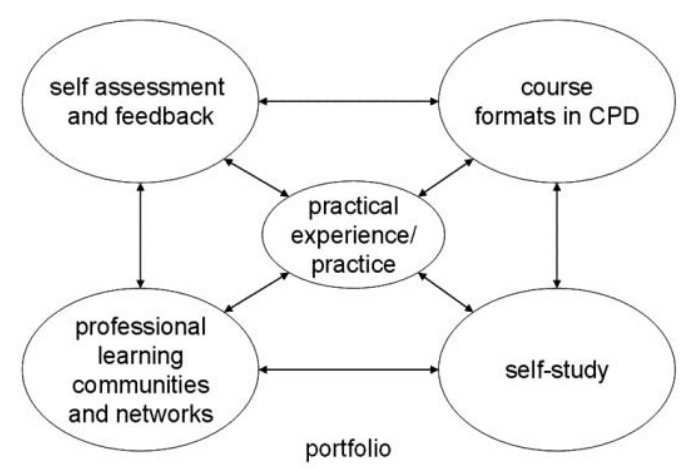

Figure 1

\section{Design of the program}

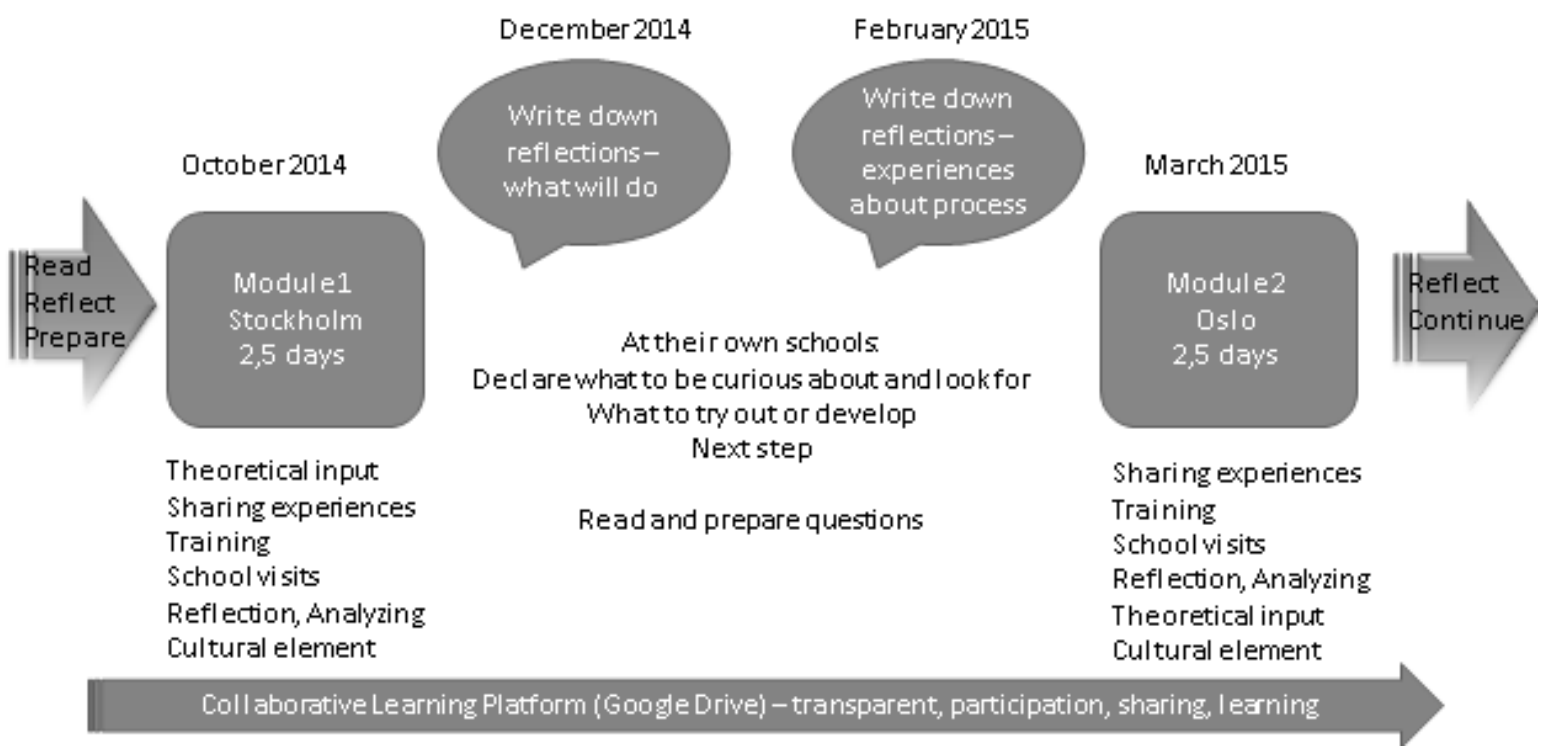

Figure 2 


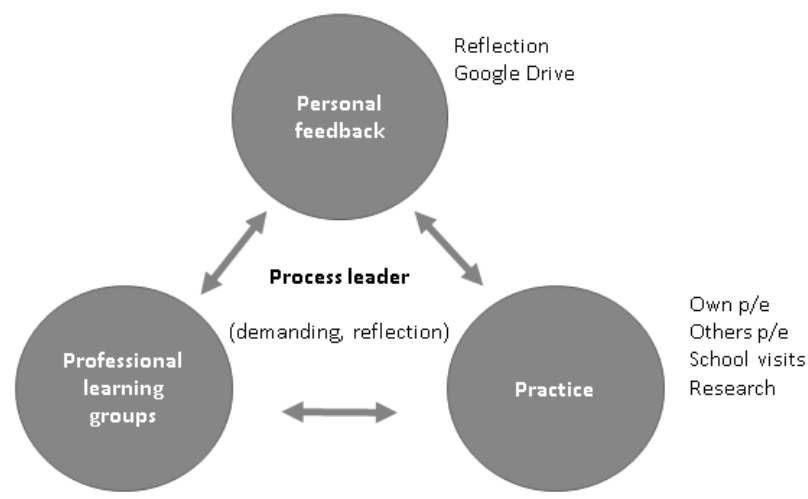

\section{Figure 3}

\begin{tabular}{|c|c|}
\hline $\begin{array}{l}\text { Documents from Google Drive - } \\
\text { examples }\end{array}$ & $\begin{array}{l}\text { Reflections after six months - } \\
\text { examples }\end{array}$ \\
\hline $\begin{array}{l}\text { ILE-principles will be integrated at } \\
\text { the whole school }\end{array}$ & $\begin{array}{l}\text { Teachers skills development } \\
\text { Diagnose/design-present situation and forward actions } \\
\text { Flexible organization-thematic topics } \\
\text { Quality work at the school based on the ILE-principals }\end{array}$ \\
\hline Collegial learning & $\begin{array}{l}\text { Diagnose/design } \\
\text { Teacher-groups with observations as base of learning and development } \\
\text { Learning walks at the school }\end{array}$ \\
\hline Distributed leadership & $\begin{array}{l}\text { Leadership is spread and shared, more teachers take responsibility } \\
\text { Teachers competence is visible, teachers share with each other } \\
\text { Other distribution of leadership between principal and vice principal } \\
\text { Delegated and more involvement in decision making }\end{array}$ \\
\hline $\begin{array}{l}\text { More focus on the instructional } \\
\text { leadership } \\
\text { AND } \\
\text { More use of ICT as aleader }\end{array}$ & $\begin{array}{l}\text { Clearer leadership-turning around a negative school culture - see a more } \\
\text { confident faculty } \\
\text { Faculty conferences-teachers more active, more use of ICT, more of } \\
\text { collegiallearning } \\
\text { Work with school vision-inspired of ILE } \\
\text { Principal iswalking around in the school-visible and active } \\
\text { Principal-more confidence }\end{array}$ \\
\hline
\end{tabular}

\section{Table 1}

